\title{
80 ANOS DOS ARQUIVOS DO INSTITUTO BIOLÓGICO
}

"Arquivos do Instituto Biológico" completou 80 anos neste ano. Esta revista científica, criada em 1928, um ano após a criação do Instituto Biológico (IB), sempre teve como escopo a publicação de artigos sobre descrições e investigações de doenças e pragas dos animais e vegetais, estando assim em conformidade com a própria missão institucional que verte sobre a sanidade animal e vegetal.

Os autores dos trabalhos que publicam na revista "Arquivos do Instituto Biológico" são procedentes tanto do próprio IB, quanto de outras instituições de ensino e pesquisa do Brasil e do exterior. Esta visibilidade conquistada pela Revista "Arquivos do Instituto Biológico" e a crescente demanda podem ser justificadas: i) pelo aumento da divulgação, a partir de 1995, deste periódico entre os Institutos de Pesquisa e as Universidades; ii) pelo acesso livre da revista, pois ela se encontra disponível, gratuitamente, para consulta no site do Instituto Biológico; iii) pelo aumento do número e diversidade institucional dos revisores científicos (ad hoc), que também passaram a publicar nesta revista eiv) pela política imposta pelas agências de fomentoe cursos de pós graduação que banem a endogenia e valorizam e incentivam as publicações realizadas em outras revistas.

Reconhecendo a importância deste periódico no cenário nacional de divulgação científica, julgamos oportuno compartilhar a comemoração dos 80 anos da revista "Arquivos do Instituto Biológico" com nossos pares, autores e editores de revistas científicas. Para isso, O Instituto Biológico, juntamente com a ABEC, promoveu o XVI Curso de Editoração Científica, nos dias 2 e 3 de outubro de 2008. Este evento superou as expectativas tanto no número de participantes quanto pela alta categoria das apresentações dos palestrantes convidados que abordaram temas atuais e de grande relevância. Participaram deste evento 167 pessoas provenientes de instituições de pesquisa e universidades, oriundas das 5 regiões geográficas do Brasil.

Como marco deste ano comemorativo cabe ressaltar, ainda, a conquista pela Revista “ Arquivos do Instituto Biológico" da certificação pela norma NBR ISO 9001:2000 - Sistema de Gestão da Qualidade com o escopo "Publicação de artigos e comunicações científicas originais, além de revisões, que contribuam para o desenvolvimento das ciências agrárias no Brasil". Esta norma é internacional e está focada nos requisitos do cliente (autores dos trabalhos) e tem, como alguns dos objetivos, atividades padronizadas, controle pleno do processo (tramitação dos trabalhos) e sua melhoria contínua. Este certificado endossa a credibilidade já conquistada ao longo desses 80 anos de existência da revista e reflete o compromisso dos "Arquivos do Instituto Biológico" com os seus autores e leitores no que se refere à qualidade das publicações científicas aqui editadas.

\author{
Silvia Regina Galleti \\ Editora chefe \\ Revista "Arquivos do Instituto Biológico" \\ Instituto Biológico - São Paulo - SP - Brasil
}

